\title{
RESPONSE OF TOMATO PLANTS TO DIFFERENT RATES OF ZINC NANOPARTICLES SPRAYING AS FOLIAR FERTILIZATION
}

\author{
A. El-Raie ${ }^{1}$; H. E. Hassan ${ }^{2}$; A. A. Abd El-Rahman ${ }^{3}$ and A. A. Arafat ${ }^{4}$
}

ABSTRACT

A field experiment was carried out on a clayey soil in Egypt cultivated with tomato plants (Lycopersicon esculentum Mill.), and irrigated with Nile water, to study the potential benefit of zinc nutrient in nanoparticles form Vis. mineral [ $\left.\mathrm{ZnSO}_{4} .7 \mathrm{H}_{2} \mathrm{O}(22.75 \% \mathrm{Zn})\right]$. The zinc nutrient forms were applied as foliar application and the studied parameters were growth, yield, days to flowering and some quality parameters. The obtained results reveal that the tomato parts dry matter, yield of fruits, and some quality properties including pigment content (Chlorophyll and lycopene), total sugars and total soluble solids (TSS) greatly increased, in general with additions of iron nutrient forms. During nanoparticle treatments, the most effective treatment was with the rate of half dose from minerals at recommended dose (ZnNPs at 50\%RD). Mineral forms in normal recommended dose (MNRD) gave nearly equal effect with ZnNPs at 50\%RD. About days to flowering treatments, the minimum number of days was accompanied with (ZnNPs at 50\%RD) followed by (MNRD). From aforementioned results, it can be concluded that, the foliar application of iron nutrients in the form of nanoparticles presented equal effects with mineral forms in the rate of half concentration from recommended dose. By these results nanoparticles application may save the amount of agrochemical used in fertilizers. The low quantities of nanoparticles were more effective than higher from ordinary source (mineral source) may be due to that nanoparticles pathway reached the target sites of plant without facing retarding factors such as permeability selection, redox reactions and charges on cell wall.

[1] Prof. of Agricultural Engineering (Supervisor) Faculty of Agriculture, Cairo Univ. Egypt.

[2] Prof. of Laser Application in Agricultural Engineering (NILES), Cairo Univ. Egypt.

[3] Prof. of Agricultural Engineering in Agricultural Engineering Institute, Agricultural Research Center (ARC), Egypt.

[4] Asc. Researcher of Soil, Water and Environmental Institute, Agricultural Research Center (ARC), Egypt. 


\section{1-INTRODUCTION}

lomato ranked in priority second after potato in the world. Egypt is
ranked sixth in the production of world tomato (FAO-STAT
2011) and shared of $6 \%$ from world production. Tomatoes are important not only because of the large amount consumed, but also because of their high health and nutritional contributions to humans. Tomato products are rich in food components that are antioxidant and considered to be a source of carotenoids, in particular lycopene and phenolic compounds Pinela et al. (2012).Foliar fertilizers are concentrated aqueous solution or suspension which must be diluted with water before applied to plant. Khatoon et al. (2011) stated that the foliar application is very fast method for providing requires elements in plants because nutrients are absorbing quickly in compare with absorption that through plant roots. Torun et al. (2001) reported that the foliar spray of micronutrients is more effective to control deficiency problem than soil application. Chinnamuthu and Murugesa (2009) stated that the word "Nano" is used in the world of science to mean one billionth. A nanometer is only ten atoms across and they added that it is worth noting nanoparticles can be made from a huge variety of bulk materials. They explicated their actions and chemical behaviors depending on chemical composition and physical properties such as size and shape of the particles. By considering that aspect it is not strange to find both positive and negative effect of nanoparticles on higher plants.

Ruffini and Roberto (2009) reported that it is ascertained the nanoparticles as agrochemicals could reduce the injury to plant tissues and amount of chemicals released into environment due to contact and interaction of plants with soil will reduce also. Remya et al. (2010) reported that the nanotechnology offers an important role in improving the existing crop management techniques. Agrochemicals are conventionally applied to crops by spraying and/or broadcasting. Usually only a very low concentration of chemicals, which is much below the minimum effective concentration required, has reached the target site of crops due to problems such as leaching of chemicals, degradation by photolysis, hydrolysis and by microbial degradation. Nanoparticles provided an efficient means to distribute pesticides and fertilizers, 
because its route in plant will be through vascular system, thus these nanoparticles can be successfully used to unload agrochemicals (fungicides, insecticides, etc.), or other substances (plant hormones, elicitors, nucleic acids) and finally leading to enhancing growth. Uzu et al. (2009) explained the route of nanoparticles when it used as foliar application. When nanoparticles were applied on leaf surfaces, it entered through the stomatal openings or through the bases of trichomes and then translocated to various tissues. Lopez et al., (2010) showed that soybean root elongation was promoted at 500mgZnONPsL-1 but reduced at higher concentration, this could be attributed to an excess of $\mathrm{Zn}$ ions released by NPs or an interaction between the NPs and root surface. The interaction of ZnONPs with plant could be influenced by the species of plants. Stampoulis et al. (2009) demonstrated that there was a positive effect of zinc oxide nanoparticles on the seed germination and root growth of zucchini seeds grown in hydroponic solution containing $\mathrm{ZnO}$ nanoparticles. Lin and Xing (2008) grew ryegrass plants with $\mathrm{ZnO}$ nanoparticles (NPs) and $\mathrm{Zn}^{+2}$ ions in nutrient solution. It was observed that $\mathrm{ZnONPs}$ and $\mathrm{Zn}^{+2}$ ions had toxic effects at higher concentrations. $\mathrm{Zn}^{+2}$ ions were more toxic than $\mathrm{ZnONPs}$ which resulting in yellowing and complete death of the plant at higher concentrations. Halvin et al. (1999) stated that, zinc has a very important role in protein and carbohydrates synthesis, cell metabolism, protection of membrane against oxygen free radicals Gupta et al. (2007) investigated the effect of zinc spray as micronutrient on clusterbean (Cyamposis tetragonoloba L.Taub). They used $\mathrm{ZnSO} 4$ and they found that the spray of zinc at any stage of crop increased chlorophyll content significantly compared to control. Cost analysis revealed maximum mean net income with two foliar applications of $\mathrm{ZnSO} 4$ along with one foliar application of Blitox-50(mixture of multimicronutrients). Cakmak (2008) reported that zinc deficiency is problem in food crops, causing decreased crop yields and nutritional quality. In most parts of cereal growing areas, soils have variety of chemical and physical problems that significantly reduce availability of $\mathrm{Zn}$ to plant roots; therefore, application of $\mathrm{Zn}$ is essential to improve zinc concentration in cereal grains. Zinc application for grains is also a great important for crop productivity which resulted better seedling vigor, 
denser stands and higher stress tolerance on potentially Zn-deficient soils. Zinc derived from foliar applications is a greater bioavailability for grains than soil application and useful in solving $\mathrm{Zn}$ deficiency. Basavarjeshwari et al. (2008) carried out a field experiment to study the effect of micronutrients on growth and yield of tomato. They evidenced that the foliar application of zinc had a significantly increased of plant height and number of branches per plant. Korezeniowska(2008) showed that the foliar application of zinc at reproductive growth stages increase grain and straw yield significantly in wheat. Bisen et al. (2006) conducted a field experiment to evaluate the effect of some micronutrients and zinc application on the growth and yield of mature sweet orange. The highest yield (80 kg per plant) and best yield per acre were recorded for zinc application among all used micronutrients. The highest pulp weight, juice content and total soluble solids (TSS) were recorded with the treatment of zinc application. Kanujia et al. (2006) performed a field experiment to ascertain the effect of micronutrients on growth and yield of cabbage var. "Golden Acre". Results revealed that the foliar application of zinc at 100 ppm gave maximum plant height during both seasons of experiment "spring and autumn".Dehnavy et al. (2004) found that the foliar application of zinc and manganese increased the total soluble sugars of safflower plants.

\section{2-1 Materials}

\section{2-MATERIALS AND METHODS}

2-1-1 Treatments: A field experiment was carried out on clayey soil cultivated with tomato plants (Lycopersicon esculentum Mill.) irrigated with Nile water. The applied treatments of the studied zinc nutrient included zinc sulfate $\mathrm{ZnSO}_{4} .7 \mathrm{H}_{2} \mathrm{O}(22.75 \% \mathrm{Zn})$ and zinc nanoparticle which supplied by Sigma Aldrich Int. Co as zinc oxide ( $\mathrm{ZnO})$, spherical shape with size $(<100 \mathrm{~nm})$ were added as foliar application, with special reference to the control treatment (untreated plants) and normal recommended dose of mineral fertilization (MNRD). The recommended dose in spraying solution was $2 \mathrm{~g} .1^{-1}$ with the rate of 600liter.fed ${ }^{-1}$. Zinc sulfate was added in the recommended dose (RD) from mineral sulfate salts fertilization as a traditional foliar fertilizer. While zinc nanoparticle (ZnNP) was added as a fraction of mineral salts rate in normal 
recommended dose as $[\mathrm{ZnNP}$ at $10 \% \mathrm{RD}, 25 \% \mathrm{RD}, 50 \% \mathrm{RD}, 75 \% \mathrm{RD}$ and $100 \%$ RD]. Foliar application of micronutrients sprayed among four times, after 30 days from planting and every 15 days uptill fruit stage. Observations were recorded for many parameters such as; dry weights of roots and shoots, fruit yield, days to flowering and some quality characters. The experiment was designed in randomized complete block design with three replicates was used, with an area of $100 \mathrm{~m}^{2}$ having the dimensions (10x10). This area was divided into 20 bands, each band extended $10 \mathrm{~m}$. The distance between each two successive bands was $50 \mathrm{~cm}$. Tomato plants were transplanted at the distance of $50 \mathrm{~cm}$ apart. Furrow irrigation was used after leveling by laser.

Soil fertilizer was applied according the recommendation of agricultural research center (ARC2003) for tomato plant production. The days from transplanting (the end of vegetative growth), flowering stage were determined. During this growth stage the dry weight of tomato shoots and roots were evaluated also, macro and micro nutrients content and uptake of shoots and roots were analyzed. The first fruit ripened taken after the date of transplanting (mature or reproduction stage). At this stage the fruit yield per plant was determined while other plant parts (shoots and roots) were determined as dry weight. The selected youngest fully expanded leaves were taken from each treated plant for determining nutrients $(\mathrm{N}, \mathrm{P}$, $\mathrm{K}, \mathrm{Fe}, \mathrm{Mn}$ and $\mathrm{Zn}$ ) and total chlorophyll; also roots content of these nutrients were determined. Tomato fruits were subjected to the different analysis to estimate the total of soluble solids (TSS), Lycopene content, total sugars and nutrient contents (Macro and Micro Nutrients). The different treatments illustrated in table (1).

Table (1) applied treatments in the experiment.

\begin{tabular}{|c|c|c|c|c|}
\hline Ser. & $\begin{array}{c}\text { Treatments } \\
\text { No. }\end{array}$ & \multicolumn{2}{|c|}{$\begin{array}{c}\text { Treatments } \\
\text { Symbol }\end{array}$} & Rate of applied micronutrient sand nanoparticles \\
\hline 1 & T0 & \multicolumn{2}{|c|}{ Control } & Control (without foliar fertilization treatments) \\
\hline 2 & T1 & \multicolumn{2}{|c|}{ MNRD } & Mineral fertilizers in Normal Recommended Dose. \\
\hline 3 & $\mathbf{T 2}$ & \multirow{5}{*}{$\mathrm{ZnNPs}$} & $10 \% \mathrm{RD}$ & $10 \% \mathrm{RD}$ of $\mathrm{Zn}$ as $\mathrm{Zn}$ nanoparticles + RD of $\mathrm{Fe}$ and $\mathrm{Mn}$. \\
\hline 4 & T3 & & $25 \% \mathrm{RD}$ & $25 \% \mathrm{RD}$ of $\mathrm{Zn}$ as $\mathrm{Zn}$ nanoparticles $+\mathrm{RD}$ of $\mathrm{Fe}$ and $\mathrm{Mn}$. \\
\hline 5 & T4 & & $50 \% \mathrm{RD}$ & $50 \% \mathrm{RD}$ of $\mathrm{Zn}$ as $\mathrm{Zn}$ nanoparticles + RD of $\mathrm{Fe}$ and $\mathrm{Mn}$. \\
\hline 6 & T5 & & $75 \% \mathrm{RD}$ & $75 \% \mathrm{RD}$ of $\mathrm{Zn}$ as $\mathrm{Zn}$ nanoparticles+ RD of $\mathrm{Zn}$ and $\mathrm{Mn}$. \\
\hline 7 & T6 & & $100 \% \mathrm{RD}$ & $100 \% \mathrm{RD}$ of $\mathrm{Zn}$ as $\mathrm{Zn}$ nanoparticles + RD of $\mathrm{Fe}$ and $\mathrm{Mn}$. \\
\hline
\end{tabular}


Table(2) Materials which were used in the studied experiment

\begin{tabular}{|c|c|c|c|c|c|}
\hline \multirow{2}{*}{\multicolumn{2}{|c|}{ characteristics }} & \multirow{2}{*}{$\begin{array}{c}\text { Soil } \\
\text { Values }\end{array}$} & \multirow{2}{*}{$\begin{array}{c}\text { Irrigation Water } \\
\text { Values }\end{array}$} & \multicolumn{2}{|c|}{ Some Properties of nanoparticles } \\
\hline & & & & Chemical formula & $\mathrm{Fe}_{2} \mathrm{O}_{3}$ \\
\hline \multicolumn{2}{|c|}{$\begin{array}{l}\text { pH(1:2.5soil:wate } \\
\text { r susp.) }\end{array}$} & 7.93 & 7.23(irrig.water) & Form & $\begin{array}{l}\text { Nano } \\
\text { powder }\end{array}$ \\
\hline \multicolumn{2}{|c|}{$\begin{array}{l}\mathrm{ECe} \quad \mathrm{dS} / \mathrm{m} \quad \text { (soil } \\
\text { sat. paste extract.) }\end{array}$} & 2.91 & 0.93(irrig.water) & Image (TEM) & Spherical \\
\hline \multicolumn{2}{|c|}{ Organic matter\% } & 1.47 & ---- & Size & $(50-100) \mathrm{nm}$ \\
\hline \multicolumn{4}{|c|}{ Soluble ions (soil me.. $\mathrm{L}^{-1}$,Water m.mole.L $\mathrm{L}^{-1}$ ) } & MP (melting point) & $1538^{\circ} \mathrm{C}($ lit $)$ \\
\hline \multicolumn{2}{|c|}{$\mathrm{Ca}^{++}$} & 9.69 & 2.39 & Surface Area & $60 \mathrm{~m}^{2} \cdot \mathrm{g}^{-1}$ \\
\hline \multicolumn{2}{|c|}{$\mathrm{Mg}^{++}$} & 4.76 & 1.84 & \multirow[t]{2}{*}{ Assay } & \multirow{2}{*}{$\begin{array}{l}97 \% \text { trace } \\
\text { metal basis }\end{array}$} \\
\hline \multicolumn{2}{|c|}{$\mathrm{Na}^{+}$} & 12.73 & 4.64 & & \\
\hline \multicolumn{2}{|l|}{$\mathrm{K}^{+}$} & 0.81 & 0.62 & \multirow[t]{4}{*}{ Density } & \multirow{4}{*}{$\begin{array}{l}{ }_{1}^{4.8-5.1} \text { g.m- } \\
\text { at } 25{ }^{\circ} \mathrm{C} \\
\text { (lit) }\end{array}$} \\
\hline \multicolumn{2}{|l|}{$\mathrm{CO}^{--}$} & 0.00 & 0.00 & & \\
\hline \multicolumn{2}{|c|}{$\mathrm{HCO}_{3}^{-}$} & 3.75 & 5.30 & & \\
\hline \multicolumn{2}{|c|}{$\mathrm{Cl}^{-1}$} & 14.45 & 3.65 & & \\
\hline \multicolumn{2}{|c|}{$\mathrm{SO}^{--}$} & 9.81 & 0.54 & Bulk Density & 0.84 g.mL $\mathrm{mL}^{-1}$ \\
\hline \multicolumn{2}{|c|}{$\begin{array}{l}\text { Available soil } \\
\text { nutrients }\left(\mathrm{mg} \cdot \mathrm{kg}^{-1}\right)\end{array}$} & \multicolumn{2}{|c|}{$\begin{array}{ll}\begin{array}{l}\text { Available } \\
\text { elements }\left(\mathrm{mg} \cdot \mathrm{kg}^{-1}\right)\end{array} & \text { water } \\
\end{array}$} & & \\
\hline $\mathrm{N}$ & 39.01 & $\mathrm{Cd}$ & 0.019 & & \\
\hline $\mathrm{P}$ & 6.13 & $\mathrm{Ni}$ & 0.087 & & \\
\hline $\mathrm{K}$ & 248.63 & Co & 0.036 & & \\
\hline $\mathrm{Fe}$ & 2.16 & $\mathrm{Fe}$ & 0.711 & & \\
\hline $\mathrm{Zn}$ & 0.78 & $\mathrm{Zn}$ & 0.907 & & \\
\hline $\mathrm{Mn}$ & 1.34 & $\mathrm{Mn}$ & 0.346 & & \\
\hline
\end{tabular}

2-1-2 Methods of analysis:- Soluble cations and anions in soil and water were measured according to Page et al.(1982) while soil organic matter and calcium carbonate content according Black (1982). Soil samples were extracted by DTPA according to Lindsay and Norvell (1978) and micronutrients in water and soil were analyzed by inductively coupled argon plasma spectroscopy (ICP) (perking elmer - 400) according to Cottenie et al. (1982). Sub samples of dried plant were wet digested using sulphoric acid mixture to analyze N, P, K, Ca, Mg, Fe, Zn and Mn. Total nitrogen was determined using micro Kjelddahl apparatus (Chapman and Part 1961). Potassium was evaluated using flame photometer, while $\mathrm{Ca}$, $\mathrm{Mg}, \mathrm{Fe}, \mathrm{Zn}$ and $\mathrm{Mn}$ were determined by atomic absorption spectrophotometry (AOAC, 1980) . Leaves were cut into small pieces and 
appropriate weight (1 gm each) were subjected to extraction of $80 \%$ solution of acetone and spectrophotometrically determination of chlorophyll a,b and total at wave lengths of (663 and 645) $\mathrm{nm}$ according to the method of (Arnon, 1965). The content of chlorophyll in solution was calculated as the following formula

Chlorophyll a (mg.g-1) $=[12.7(\mathrm{~A} 663)-2.69(\mathrm{~A} 645)] \times \mathrm{V} / 1000 \times \mathrm{W}$. Chlorophyll b (mg.g-1) $=[22.9(\mathrm{~A} 645)-4.68(\mathrm{~A} 663)] \times \mathrm{V} / 1000 \times \mathrm{W}$. Total chlorophyll (mg.g-1) $=[20.2(\mathrm{~A} 645)-8.02(\mathrm{~A} 663)] \times \mathrm{V} / 1000 \mathrm{x}$ W. Where: $\mathrm{A}=$ Absorbance of specific wavelength. $\mathrm{V}=$ final volume of chlorophyll extract in $80 \%$ acetone. W= weight of sample.

The TSS of the harvested fruit juice was determined by hand refractometer (Atago N-20E) and the measured values (\%Brix) were converted to a standard temperature condition of $20^{\circ} \mathrm{C}$ Ranganna (1994). Lycopene concentration of tomato fruits were measured spectrophotometrically using a modified method based on Fish et al (2002). Total sugar were extracted in $10 \mathrm{ml}$ of $80 \%$ anhydrous alcohol by boiling $0.1 \mathrm{~g}$ dry powdered sample for $30 \mathrm{~min}$ at $80^{\circ} \mathrm{C}$ followed by centrifugation at $5,000 \mathrm{~g}$ for $10 \mathrm{~min}$ and subsequent procedures was followed using the Anthrone reagent method (Sen et al., 2005). Nanoparticles manufacturing by (Sigma Aldrich Methods of Nanomaterials 2009).

\section{3-RESULTS AND DISCUSSIONS}

3-1 Effect of nanoparticles as a foliar fertilization at different rates of mineral fertilizers on growth and yield of tomato plants:

3-1-1 Effect on growth of tomato plants. Data of tomato growth parameters are presented in table (3) and figure (1) revealed that the treatments (No. 5) including the half dose of mineral fertilizers in normal recommended dose (MNRD) were the best treatments of nanoparticles fertilizations with the respect to dry weights (DWs) of tomato shoots, roots and whole plants. The treatment No.5 consisted of iron nanoparticles in the rate of 50\%RD of $\mathrm{Zn}$ was the highest value of tomato (DWs), followed with treatments No.2. Considering the treatments of nanoparticles foliar fertilization spraying on tomato plants, we can notice that the nanoparticles in the half dose nearly equal with the fully dose of recommended mineral fertilization. While when the rate of nanoparticles reduced or increased over the rate of half mineral 
recommended dose, the values of tomato parts dry weight will be reduced. Referring to the rate of increase (relative increase) in tomato growth parameters as resulted to control, it is clear that this increase ranged from about 106.45, 64.88 and $69.46 \%$ over the control, in case of treatment No.3 [which received zinc nanoparticle in the rate of $10 \%$ mineral fertilization from recommended dose] up to 208.29, 184.46 and $187.09 \%$ for the treatment No.5 including zinc nanoparticle in the rate of half mineral fertilization at recommended dose, with respect to the dry weights of tomato roots, shoots and whole plant. In general, the investigated treatments could be arranged descendingly according to their positive effect on tomato growth (DWs of tomato parts) as: - MNRD> ZnNPs at 50\%RD > 75\%RD > 25\%RD > 100\%RD $>10 \% \mathrm{RD}>\mathrm{Control}$. The results may suggest that nanoparticles fertilization in the half rate of recommended mineral fertilization gave the positive effect on growth of tomato plants, while the higher or lower than this rate gave the negative effects. Also the mineral fertilization in the recommended dose nearly gave the equal results with nanoparticles in the rate of half mineral fertilization at recommended dose. The improving in the growth and dry matter yield of tomatoes related strongly with the balance amount of nutrients. An appropriate nutrient supply is always a prerequisite and crucial to reach high yields in tomato, however the deficiency or excess in nutrients requirement affected negatively on growth status and yield of tomato plants. The improvement in the growth may be due to the involvement of micronutrients in different physiological process like enzyme activation, electron transport, chlorophyll formation and stomatal regulation which ultimately resulted in greater dry matter. Small concentration of applied nanoparticle had a stimulating effect on plant growth while the enhanced concentration induced an inhibitory effect. This action may be due to the uptake pathway of foliar nanoparticles which was through stomatal pores along the leaf blade. This pathway differed fundamentally from the cuticle foliar uptake (ionic pathway for mineral fertilization). The stomatal uptake doesn't require infiltration of solutions by dynamic mass flow but is caused by diffusion of solutes or suspended particles probably in water absorbed to the walls of the stomatal pores, therefore this pathway is accessible for any water-soluble solutes even for small particles irrespective of charge or molecular weight and enables transport much higher than across the cuticle. 
Table (3) Effect of different treatments on dry matter of tomato roots, shoots and whole plant at flowering stage.

\begin{tabular}{|c|c|c|c|c|c|c|c|c|c|}
\hline \multirow[b]{2}{*}{ Ser. } & \multirow{2}{*}{$\begin{array}{l}\text { Treatments } \\
\text { Number }\end{array}$} & \multirow{2}{*}{\multicolumn{2}{|c|}{ Treatments Symbol }} & \multicolumn{6}{|c|}{ Dry weights of tomato $\left(g_{\text {plant }}{ }^{-1}\right)$} \\
\hline & & & & Roots & $\begin{array}{l}\text { Relative } \\
\text { increase }\end{array}$ & Shoots & $\begin{array}{l}\text { Relative } \\
\text { increase }\end{array}$ & $\begin{array}{l}\text { Whole } \\
\text { plant }\end{array}$ & $\begin{array}{l}\text { Relative } \\
\text { increase }\end{array}$ \\
\hline 1 & T0 & \multicolumn{2}{|c|}{ Control. } & 2.17 & 0.00 & 17.51 & 0.00 & 19.68 & 0.00 \\
\hline 2 & $\mathrm{~T} 1$ & \multicolumn{2}{|c|}{ MNRD } & 6.71 & 209.21 & 49.81 & 184.46 & 56.52 & 187.19 \\
\hline 3 & $\mathrm{~T} 2$ & \multirow{5}{*}{ ZnNPs } & $10 \%$ RD & 4.48 & 106.45 & 28.87 & 64.88 & 33.35 & 69.46 \\
\hline 4 & $\mathrm{~T} 3$ & & $25 \%$ RD & 5.38 & 147.93 & 38.71 & 121.07 & 44.34 & 125.30 \\
\hline 5 & $\mathrm{~T} 4$ & & $50 \%$ RD & 6.69 & 208.29 & 49.81 & 184.46 & 56.50 & 187.09 \\
\hline 6 & $\mathrm{~T} 5$ & & $75 \%$ RD & 5.63 & 159.45 & 39.75 & 127.01 & 45.13 & 129.32 \\
\hline 7 & T6 & & $100 \% \mathrm{RD}$ & 4.67 & 115.21 & 29.45 & 68.19 & 34.12 & 73.37 \\
\hline
\end{tabular}

Dry weights evaluated per one plants NPs=Nanoparticles $\mathbf{R} . \mathbf{D}=$ Recommended Dose $\mathbf{M N R D}=$ Mineral fertilizers in Normal Recommended Dose

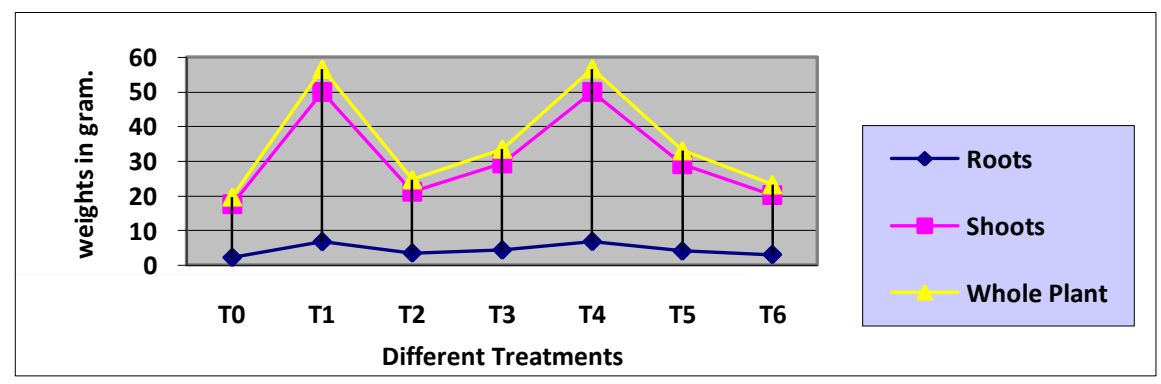

Fig(1) Effect of different treatments on tomato dry weights

3-1-2 Effect on yield of tomato plants. Results scheduled in table (4) and illustrated in figures (2) indicated that the dry matter weights of tomato roots and fruits yield responded to the used treatments almost typically according to the descending order:- ZnNPs at 50\%RD > MNRD> 25\%RD $>75 \% \mathrm{RD}>10 \% \mathrm{RD}>100 \% \mathrm{RD}>$ Control . Considering the rate of increase in tomato parts and fruit yield as related to control, it is clear that this increase could be arranged as the following:- The relative increase values of the tested nanoparticle treatments ranged from about 71.43, $42.17,44.82$ and 32.00 up to $236.00,115.32,126.25$ and152.00 for tomato roots, shoots and fruits yield, respectively. Such results of zinc nutrient effects on growth and yield of tomato plants may be according to its role in physiological and biochemical process. Zinc increased the rate of photosynthesis and resulted to increase yield of tomato. At the small 
amount of applied nutrients, yield tomato had been declined due to micronutrient deficiency while high rate of used nutrients may cause toxicity and will gave negatively effects on yield and growth parameters.

Table (4) Effect of different treatments on yield and dry matter of tomato roots, shoots and whole plant at reproduction stage

\begin{tabular}{|c|c|c|c|c|c|c|c|c|c|c|c|}
\hline \multirow[b]{2}{*}{$\mathrm{Sr}$} & \multirow[b]{2}{*}{$\begin{array}{l}\text { Treatment } \\
\text { Number }\end{array}$} & \multirow{2}{*}{\multicolumn{2}{|c|}{ Treatments Symbol }} & \multicolumn{6}{|c|}{ Dry weights of tomato (g. plant ${ }^{-1}$ ) } & \multicolumn{2}{|c|}{ Yield $\left(\right.$ Kg. plant $\left.^{-1}\right)$} \\
\hline & & & & Roots & R.I & Shoots & R.I & $\begin{array}{l}\text { Whole } \\
\text { plant }\end{array}$ & R.I & Yield & R.I \\
\hline 1 & T0 & \multicolumn{2}{|c|}{ Control. } & 3.50 & $\mathbf{0 . 0 0}$ & 35.17 & 0.00 & 38.67 & 0.00 & 0.75 & 0.00 \\
\hline 2 & T1 & \multicolumn{2}{|c|}{ MNRD } & 11.61 & 231.71 & 75.45 & 114.53 & 87.06 & 125.14 & 1.86 & 148.00 \\
\hline 3 & $\mathbf{T 2}$ & \multirow{5}{*}{ ZnNPs } & $10 \%$ RD & 6.79 & 94.00 & 51.31 & 45.89 & 58.10 & 50.25 & 1.01 & 34.66 \\
\hline 4 & T3 & & $25 \%$ RD & 8.91 & 154.57 & 64.21 & 82.57 & 73.12 & 89.10 & 1.41 & 88.00 \\
\hline 5 & T4 & & $50 \%$ RD & 11.76 & 236.00 & 75.73 & 115.32 & 87.49 & 126.25 & 1.89 & 152.00 \\
\hline 6 & T5 & & $75 \%$ RD & 8.31 & 137.43 & 63.78 & 81.35 & 72.09 & 86.42 & 1.34 & 78.66 \\
\hline 7 & T6 & & $100 \%$ RD & 6.00 & 71.43 & 50.00 & 42.17 & 56.00 & 44.82 & 0.99 & 32.00 \\
\hline
\end{tabular}

*Dry weight evaluated per one plant and fruit yield evaluated per one plant R.I=Relative Increase

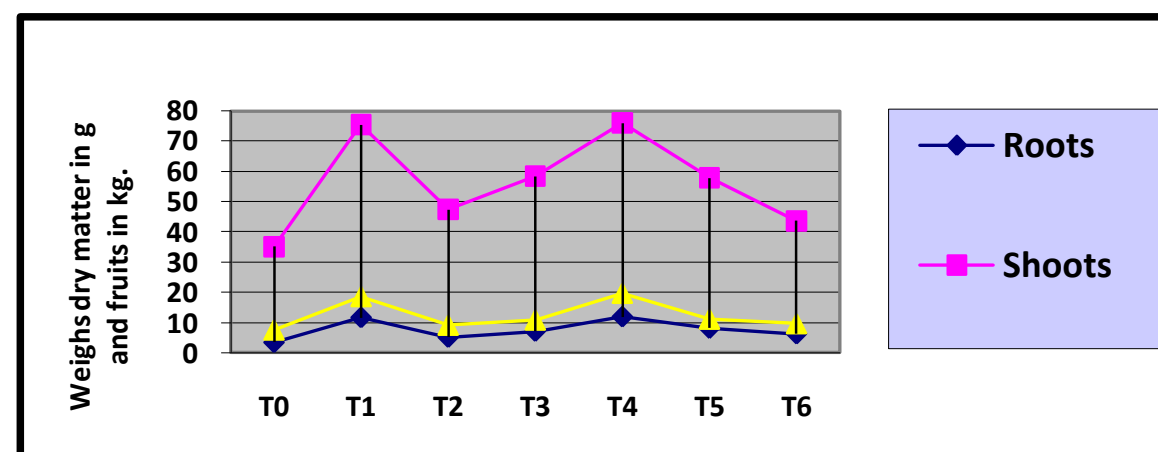

Fig(2) Effect of different treatments on tomato yield and dry weights

\section{3-1-2 Effects of nanoparticles as a foliar fertilization at different rates} of mineral fertilizers on days to flowering:- Regarding days to flowering, the results obtained from table (5) and figure(3) were indicated that the treatment No.5 (T4) including the zinc nanoparticle at half dose of normal mineral fertilization at recommended dose dominated with minimum number of days after transplanting to bear flowers followed by treatments No.2 (T1) which including fully dose of only normal mineral fertilization at recommended dose. However other nanoparticle treatments of lower or higher than the half dose of normal recommended dose were observed delaying in the bearing of flowers. Days to flowering were 
related to improvement in nutrient metabolism in plant which may result in more growth activation and enhanced the plant flowering status in plant. The escalation in tomato flowers was due to increase vegetative growth of tomato and enhanced nutrients uptake due to foliar application that resulted in increasing assimilation rate and the biosynthesis's accumulation consequently by optimal availability of some required nutrients. Moreover the foliar application of micronutrients enhanced the growth and flowering due to the availability of these nutrients and the easiness of absorbing them via leaves that fulfill the optimal nutritive requirements of tomato plants while the deficiencies of nutrients were impeding the crops growth and yield; therefore the endowment of these nutrients not only fulfilled the nutritional requirements of tomato crop but also helpful in increasing the growth, flowering and yield of tomato.

Table (5) Effect of different treatments on days to flowering

\begin{tabular}{|c|c|c|c|c|}
\hline Ser. & Treatments No. & \multicolumn{2}{|c|}{ Treatments Symbol } & Days to flowering \\
\hline 1 & T0 & \multicolumn{2}{|c|}{ Control } & 75 \\
\hline 2 & T1 & \multicolumn{2}{|c|}{ MNRD } & 47 \\
\hline 3 & $\mathrm{~T} 2$ & \multirow{5}{*}{ ZnNPs } & $10 \% \mathrm{RD}$ & 60 \\
\hline 4 & T3 & & $25 \% \mathrm{RD}$ & 53 \\
\hline 5 & T4 & & $50 \% \mathrm{RD}$ & 45 \\
\hline 6 & T5 & & $75 \% \mathrm{RD}$ & 54 \\
\hline 7 & T6 & & $100 \% \mathrm{RD}$ & 57 \\
\hline
\end{tabular}

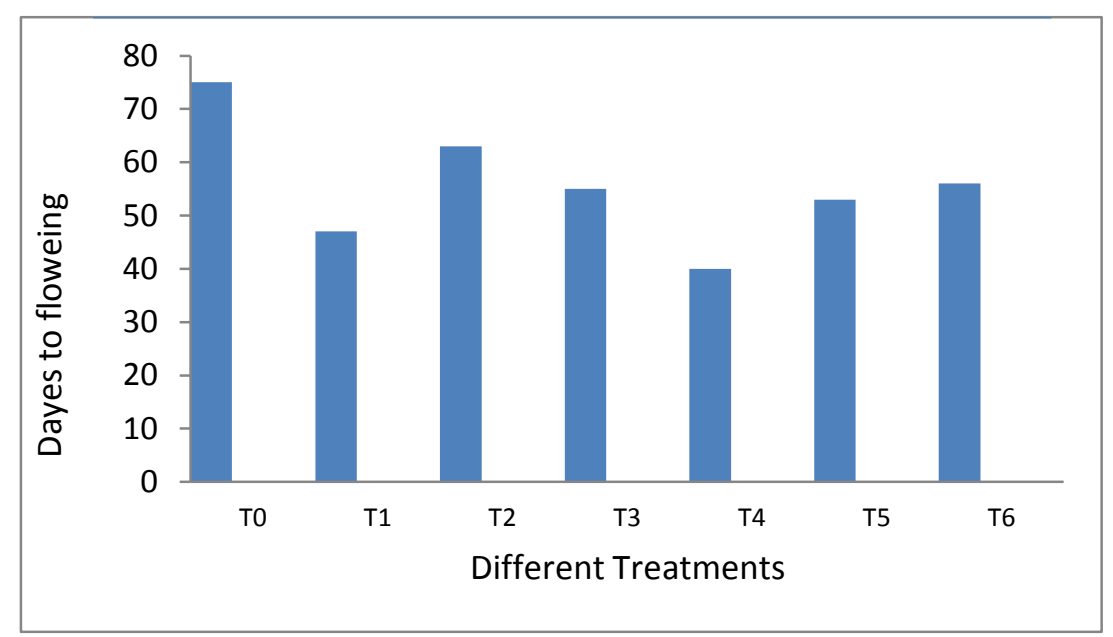

Fig(3) Effect of different treatments on the days of flowering 


\section{3-1-3 Effect of nanoparticles as a foliar fertilization at different rates of mineral fertilizers on some quality properties of tomato leaves and} fruits: Data in table (6) and figure (4) showed that there were positive effects in quality properties of tomato plants due to forms of nutrient treatments as compared with the treatment of control. These effects could be summarized as the following:

1 -All treatments indicated a positive response to foliar application of nutrients on tomato plant, as compared with the control treatment, which presented the lowest values of tomato quality properties. These values were $\left[43 \mathrm{mg} \cdot \mathrm{kg}^{-1} ;(2.18\right.$ and 2.58$) \% ;\left(0.58,0.29\right.$ and 1.22) $\mathrm{mg} \cdot \mathrm{g}^{-1}$ ] for lycopene; total soluble solids (TSS); total sugars; chlorophyll a, chlorophyll $\mathrm{b}$ and total chlorophyll.

2-The nanoparticle treatment in the rate of half dose of mineral fertilization at the rate of normal recommended dose (50\%RD) was the best treatment from all nanoparticle treatments for tomato quality properties. The values of quality properties under this rate of application (ZnNPs at $50 \% \mathrm{RD}$ ) were; $214 \mathrm{mg} \cdot \mathrm{kg}^{-1}$ fresh weight for tomatoes fruit lycopene; $6.41 \%$ for total soluble substances (TSS) of tomatoes fruit; $5.48 \%$ for total sugars of tomatoes fruit and 1.92; 0.97 and $2.89 \mathrm{mg} . \mathrm{g}^{-1}$ fresh weight for chlorophyll $\mathrm{a}$; chlorophyll $\mathrm{b}$ and total chlorophyll of tomato leaves.

Meanwhile values of tomato quality properties under the treatment of mineral fertilization at the rate of normal recommended dose (MNRD) were: 213 mg. $\mathrm{kg}^{-1}$ for tomatoes lycopene; $2.18 \%$ for total soluble substances (TSS) of tomatoes fruit; $2.58 \%$ for total sugars of tomatoes fruit and 1.87, 0.93 and 2.80) $\mathrm{mg} \cdot \mathrm{g}^{-1}$ fresh weight for chlorophyll a, chlorophyll $b$ and total chlorophyll, respectively. 3-The values of tomato quality properties decreased with other rates of nanoparticle treatments. The relative increases of tomato fruits lycopene under different nanoparticle treatments were 46.51, 111.63, 127.91 and $81.41 \%$ for the treatments of $\mathrm{ZnNPs}$ at $10 \% \mathrm{RD}, 25 \% \mathrm{RD}, 75 \% \mathrm{RD}$, and $100 \% \mathrm{RD}$, respectively. While the maximum value $402.33 \%$ was accompanied with $\mathrm{ZnNPs}$ at $50 \% \mathrm{RD}$. The same trend was found with total soluble substances (TSS) of tomato fruits, the maximum values of relative increase was $194.04 \%$ under the treatments of ZnNPs at 50\%RD, while 
other values were $28.44,70.18,82.11$ and $33.48 \%$ under the treatments of ZnNPs at $10 \% \mathrm{RD}, 25 \% \mathrm{RD}, 75 \% \mathrm{RD}$ and $100 \% \mathrm{RD}$. Also same trend with tomato fruits lycopene and TSS was found for total sugars of tomato fruits, the maximum value of relative increase was $112.40 \%$ under the treatments of $\mathrm{ZnNPs}$ at $50 \% \mathrm{RD}$. The other values were 11.24, 46.12, 33.33 and $1.16 \%$ under the treatments of $\mathrm{ZnNPs}$ at $10 \% \mathrm{RD}, 25 \% \mathrm{RD}$, $75 \% \mathrm{RD}$ and $100 \% \mathrm{RD}$, respectively. The same trend with other quality properties of tomato fruits was found for total chlorophyll of tomato leaves, the maximum value of relative increase was $136.88 \%$ under the treatment of $\mathrm{ZnNPs}$ at $50 \% \mathrm{RD}$ while other values were1.64, 22.13, $40.16,4.11 \%$ under the treatments of $\mathrm{ZnNPs}$ at $10 \% \mathrm{RD}, 25 \% \mathrm{RD}$, $75 \% \mathrm{RD}, 100 \% \mathrm{RD}$, respectively. From the preceding results, it was concluded that the beneficial effects of mineral fertilization at fully dose of normal recommended dose (MNRD) on quality parameters were nearly in the line with nanoparticle treatments in the rate of half dose of mineral fertilization at normal recommended dose (NPs at 50\%RD).

Table (6) Effect of different treatments on tomato quality parameters

\begin{tabular}{|c|c|c|c|c|c|c|c|c|c|c|}
\hline \multirow{3}{*}{ Sr. } & \multirow{3}{*}{\multicolumn{3}{|c|}{ Treatments }} & \multicolumn{3}{|c|}{ Fruit Properties } & \multicolumn{4}{|c|}{ Leaves Properties } \\
\hline & & & & \multirow[t]{2}{*}{ Lycopen } & \multirow[t]{2}{*}{ TSS } & \multirow{2}{*}{$\begin{array}{c}\text { Total } \\
\text { Sugar }\end{array}$} & \multicolumn{2}{|c|}{ Chlorophyll Content } & \multirow{2}{*}{$\begin{array}{c}\text { Ratio } \\
\mathbf{a} / \mathbf{b}\end{array}$} & \multirow[t]{2}{*}{ Total } \\
\hline & & & & & & & $\mathbf{a}$ & b & & \\
\hline \multirow{2}{*}{1} & \multirow{2}{*}{\multicolumn{2}{|c|}{ Control }} & Content & 43.00 & 2.18 & 2.58 & 0.85 & 0.29 & 2.93 & 1.22 \\
\hline & & & R.I\% & 0.00 & 0.00 & 0.00 & 0.00 & 0.00 & & 0.00 \\
\hline \multirow{2}{*}{2} & \multirow{2}{*}{\multicolumn{2}{|c|}{ MNRD }} & Content & 213.00 & 6.31 & 5.43 & 1.87 & 0.93 & 201 & 2.80 \\
\hline & & & R.I \% & 395.35 & 189.44 & 110.46 & 120.00 & 220.69 & 2.01 & 129.51 \\
\hline \multirow{2}{*}{3} & \multirow{2}{*}{\multicolumn{2}{|c|}{$10 \% \mathrm{RD}$}} & Content & 56.00 & 2.80 & 2.87 & 0.87 & 0.38 & 231 & 1.24 \\
\hline & & & R.I \% & 30.23 & 28.44 & 11.24 & 2.35 & 31.03 & 2.01 & 1.64 \\
\hline \multirow{2}{*}{4} & \multirow{8}{*}{ Zn NPs } & \multirow{2}{*}{$25 \%$ RD } & Content & 87.00 & 3.71 & 3.77 & 0.91 & 0.58 & \multirow{2}{*}{1.57} & 1.49 \\
\hline & & & R.I \% & 102.32 & 70.18 & 46.12 & 7.05 & 100.00 & & 22.13 \\
\hline \multirow{2}{*}{5} & & \multirow{2}{*}{$50 \%$ RD } & Content & 214.00 & 6.41 & 5.48 & 1.92 & 0.97 & \multirow{2}{*}{1.98} & 2.89 \\
\hline & & & R.I \% & 397.67 & 194.04 & 112.40 & 125.88 & 234.48 & & 136.88 \\
\hline \multirow{2}{*}{6} & & \multirow{2}{*}{$75 \%$ RD } & Content & 97.00 & 3.97 & 3.44 & 1.04 & 0.67 & \multirow{2}{*}{1.55} & 1.71 \\
\hline & & & R.I \% & 125.58 & 82.11 & 33.33 & 22.35 & 131.03 & & 40.16 \\
\hline \multirow{2}{*}{7} & & \multirow{2}{*}{$100 \% \mathrm{RD}$} & Content & 77.00 & 2.91 & 2.61 & 0.86 & 0.41 & \multirow{2}{*}{2.11} & 1.27 \\
\hline & & & R.I \% & 79.11 & 33.48 & 1.16 & 1.17 & 41.38 & & 4.11 \\
\hline
\end{tabular}


The contribution of these treatments for improvement the quality parameters were referred to the involvement and stimulating effects of zinc as a micronutrient in different physiological processes such as enzyme activation, electron transport, photosynthesis process and biochemical reactions in plant cell. Nanoparticles offered an improving in yield and growth by spraying lower quantity than mineral fertilization because the application of nanoparticles was more effective to reach the target site of treated plant and can transport to specific other sites throughout the plant vascular system then these nanoparticles can be successfully used to unload chemical into localized areas tissues Remya et al. (2010).
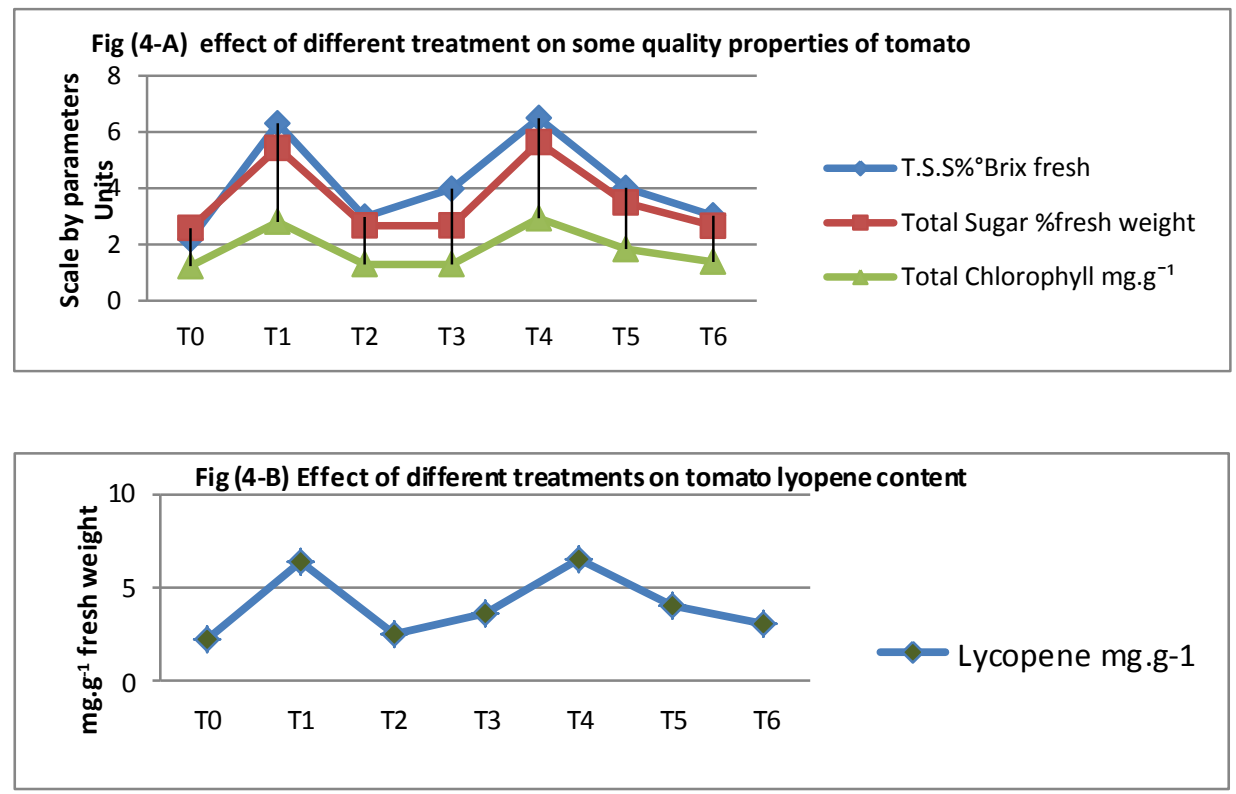

Conclusions. This study presented the following results:- - The effects of foliar application of nanoparticle on growth, yield, days to flowering and quality properties were positive in low quantity as compared with other ordinary chemicals (such as minerals). The rate of nanoparticles in half dose of mineral fertilization at normal recommended dose may be nearly equal with fully dose. -Nanoparticles pathway to plant tissues was through pores and stommata while ions nutrient which derived from minerals dissolves in water entered plant through cuticle pathway.The 
nutrients faced retarding factors in cuticle pathway such as permeability selection, redox reaction and charges on cell wall. The promising conclusions of reducing the application of chemicals had the benefits effect on health, economic and environment. More studies should be carried out in this field to get suitable recommendations of utilizing agrochemicals or fertilizers.

\section{REFERENCES}

(AOAC) Association of Official Analytical Chemists(1980)Official methods of analysis. $15^{\text {th }}$ ed.Wash.DC.p.1201

\section{ARC: Agriculture Research Center of Agriculture Ministry, Egypt} (2003). Recommendations for tomato cultivation and production. Bulletin 408; 2003. Published by ARC; Giza, Egypt.

Arnon, D.I.(1965).Photosynthesis by isolated chloroplast. Biphys.20:440-461. Basavarjeshwari, C.; R.P., Smithaand and K.C., Ukkund (2008) Effect of foliar application of micronutrients on growth and yield components of tomato. Karn.J.Agric.Sci.21(3): $428-430$.

Bisen, R.,K.; S., Deepak and H.P, Agrawal (2006) Drip irrigation scheduling, growth and yield of sweet orange. Env. and Eco. J. 24 (4): $714-719$.

Black , C . A . (1982) Methods of Soil Analysis .Soil Sci . Soc . of America, Inc . Pub. Matison Wisconsin, U. S .A.

Cakmak, I. (2008) Enrichment of cereal grains with zinc: Agronomic or genetic biofortification Plant Soil 302: 1-17.

Chinnamuthu, C.R. and B., Murugesa(2009) Nanotehnology and Agroecosystem .Madras Agric. J., 96 (1-6): 17-31.

Chapman, H.D. and P.E., Pratt (1961) Methods of analysis for soil, plant and water. Division of Agriculture Science, University of California. Riverside. Soil Sc. J. 93 (1) pp 67-68.

Cottien, A.; M., Verloo; L., Kieken; G., Velghe and R., Comerlynch (1982) "Chemical analysis of plants and soils". Fac. Agric., State Univ.,Gent, Belgium. 
Day, SC. (2000) Tomato crop in vegetable growing. Agrobios, New Dehli, India, 2000: 59-61.

Dehnavy, M.M.; S.A.M.M., Sanavy; A., Sorushzadeh and M., Jalali(2004) Changes in proline, total soluble sugars, SPAD and chlorophyll fluorescence in winter safflower cultivars under drought stress and foliar application of zinc and manganese. Biaban J. 9(1):93-109.

(FAO) Food Agriculture Organization of United Nations, Rome (2011) FAO stat database available from www.fao.org

Fish W.W.; P.V., Perkins and J.K., Collins (2002) J. Food Comp. Anal. 15,309 .

Gupta, P.P.; B.D., Yadav and U.N., Joshi (2007) Effect of micronutrients on major diseases of cluster bean (Cyamopsis tetragonoloba $\mathrm{L}$. Taub). Journal of arid legumes. 4(1):47-51.

Halvin, J.L.; J.D., Beaton; S.L.,Tisdale and L., Nelson (1999) Soil fertility and fertilizers. An introduction to nutrient mangament $6^{\text {th }}$ Ed.Prentice Hall, New Jercy.

Kanujia, S.P.; Nayeema and S., Naryan (2006) Effect of micronutrients on growth and yield of cabbage (Brassica oleracea var. capitata L.) Applied Bio. Research J. 8(1/2):15-18.

Khatoon Y.; R., Mahmod and R.M., Sayed (2011) Effect of bio-phoshate and chemical phosphorus fertilizer accompanied with micronutrient foliar application on growth, yield and yield components of maiz (single cross 704).Australian Journal of crop science. 5(2): 175-180.

Korzeniowska, J. (2008) Response of ten winter wheat cultivar to boron foliar application in a temperate vlimate (South West Poland).Agron Res. J. 6: 471-476.

Linsday, K.L. and W.A., Norvell (1987) Development of DTPA soil test for zinc, iron, manganese and copper. Soil. Am. J. 42: 421-428.

Lin $\mathrm{D}$ and B., Xing (2008) Root uptake and phytotoxicity of $\mathrm{ZnO}$ nanoparticles. Environ Sci Technol. 42:5580-5585. 
Lopez M.M.L; C.E., Botez, V.J.R., Peralta and T.J.L., Gardea (2010)

Evidence of the differential biotransformation and genotoxicity of $\mathrm{ZnO}$ and $\mathrm{CeO} 2$ nanoparticles on soybean (Glycine max) plants. Environ Sci Technol. 44:7315-7320.

Page, A.L.(1982)"Methods of soil analysis" II chemical and Microbiological properties.(Ed.2)soil.Sci.Am.Inc., Madison, W.I.

Pinela J, Barros L, Carvalho AM, Ferreira IC (2012). Nutritional composition and antioxidant activity of four tomato (Lycopersicon esculentum L.) farmer' varieties in Northeastern Portugal homegardens. Food Chem Toxicol 50(3-4):829-834.

Ranganna, S. (1994) Manual of Analisis of Fruit and Vegetable Products. Tata McGraw- lull Publishing Company Limitted, New Delhi, 11- 12 p.

Remya N.; Y. Yoshida and D. S., Kumar(2010) Nanoparticulate material delivery to plants. Plant Science 179: 154-163

Ruffinim, C.M. and C., Roberto (2009) Nanotechnology and higher plants. Caryologia Journal: 62(2): 161-165.

Sen S; A., Bhattacharya; D., Mazumder; H., Sen; A.K., Das; S., Pal (2005) Nutrient and antinutrient composition of cormels of colocasia esculenta var antiquorum. J. Veg. Sci. 11:17-34.

Sigma Aldrich, Methods of Nanomaterials Material Matters (2009) Bulltein vol.4 No.1 (ISSN 1933-9631) is publication of Aldrich Chemical Co.Inc:Aldrich is a member of Sigma-Aldrich Group@2009Sigma-Aldrich Co

Stampoulis D; S.K., Sinha and J.C., White (2009) Assay-dependent phytotoxicity of nanoparticles to plants. Environ Sci Technol. 43:9473-9479.

Torun A.; A., Yilmaz; S., Eker and I., Cakmak (2001) Effect of zinc fertilization on grain yield and shoot concentrations of zinc, boron and phosphorus of 25 wheat cultivars grown on a zinc deficient and boron toxic soil. Journal Plant Nutrition. 2: 1817-1829.

Uzu, G.; S., Sobanska; G., Sarret.; M., Munoz and C., Dumat (2009) Foliar lead uptake by lettuce exposed to atmospheric pollution. Environ. Sci. Technol. 44: 1036 - 1042. 


\title{
الملخص العربي
}

استجابة نباتات الطماطم لمعدلات مختلفة من التسميد الورقى للزنك النانو.

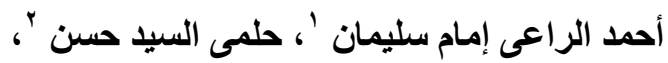

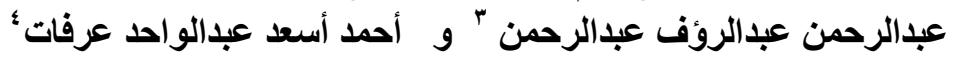

أجريت تجربة حقلية لتقييم استجابة التسميد الورقى من الزنك على نباتات الطماطم المنزر عة فى في أرض طينية تستخدم الرى بالغمر. حيث تم الرش بعنصر الزنك فى صورة أكسيد نانو بمعدلات

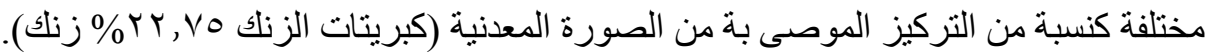

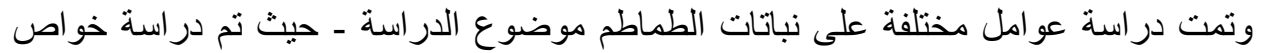

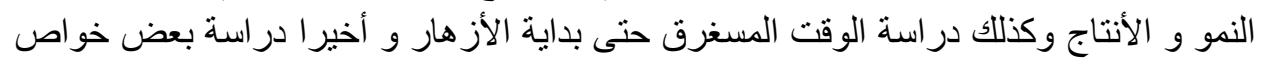

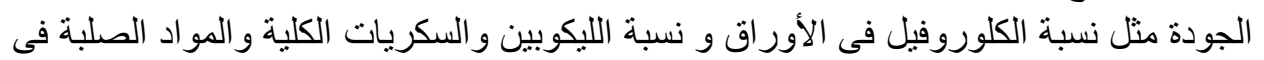
الثمار.

وقد أوضحت النتائج تحسن كل من صفات النمو و المحصول وكذلك صفات الجودة كما انخفضت المدة الزمنية للأز هار مع المعدل الموصى بة من الزنك المعدنى و الذى أعطى نتائج مماتلة للزنك

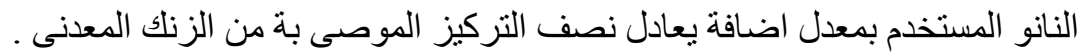

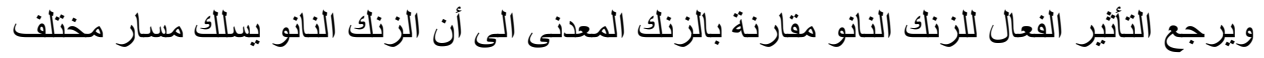

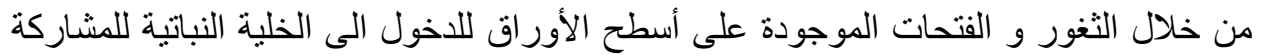
فى عمليات التمثيل الغذائى بينما الزنلك المعدنى يدخل من خلال طبقة الكيوتيكل و التى يتعرض الته

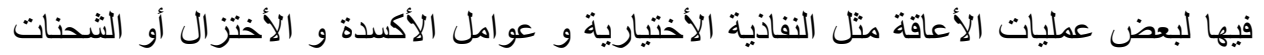
المتنافرة على جدر الخلايا. وبذللك فانة يمكن استخلاص أن استخدام الزنك النانو كمصدر للتسميد الورقى بعنصر الزنك الكي

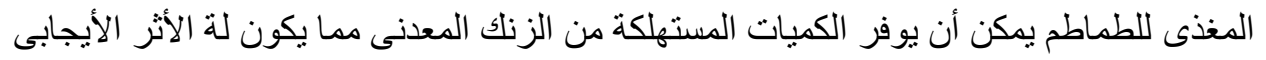
على التغذية من الطماطم وكذلك تحسن الخواص البيئية لكل من التربة و المياة الجوفية نتيجة التقليل فى استخدام الكيماويات بصفة الطئة عامة.

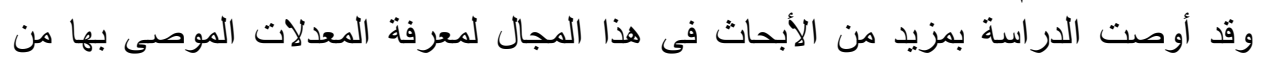
العناصر الغذائية المختلفة (فى صورة النانو) على المحاصيل المختلفة.

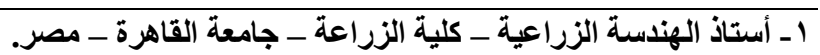

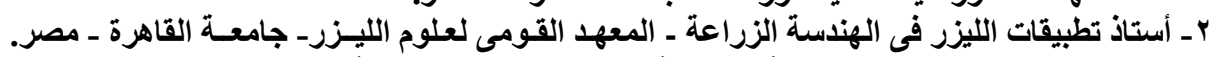

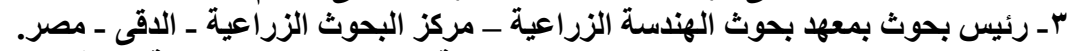

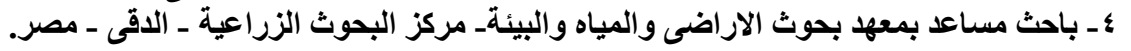

